DOI: 10.15503/onis2014-102-109

\title{
SŁUŻEBNOŚCI OSOBISTE W PODATKACH MAJĄTKOWYCH
}

\author{
Anna Hnatów, anna.hnatow@gmail.com \\ Uniwersytet im. Adama Mickiewicza w Poznaniu \\ Wieniawskiego 1, 61-712 Poznań
}

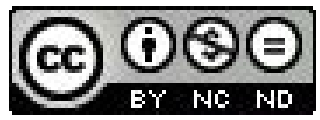

\section{STRESZCZENIE}

Służebności osobiste wywołują odmienne skutki podatkowe w zależności od tego, czy zostały ustanowione odpłatnie czy nieodpłatnie. W ostatnim przypadku istotne jest odróżnienie ich od służebności gruntowych. W artykule starano się przedstawić granicę pomiędzy obydwoma służebnościami oraz istotę opodatkowania służebności osobistych w świetle podatku majątkowego poprzez pryzmat elementów konstrukcyjnych podatku.

Słowa kluczowe: służebności osobiste, służebności gruntowe, podatek od czynności cywilnoprawnych, podatek od spadków i darowizn

\section{Personal servitudes in property taxes}

\section{Abstract}

Personal servitudes cause different tax consequences depending on whether they have been established for consideration or free of charge. In the latter case, it is important to distinguish them from the servitude of groundwater. The article aims to show the border between the two servitudes and present the issue of taxation in case of personal servitudes.

Key words: Personal servitudes, servitude of groundwater, CLAT, tax on inheritance and gifts

Służebności, będąc ograniczonym prawem rzeczowym, są również prawem majątkowym, które podlega opodatkowaniu na gruncie podatków majątkowych. Podobniejak w przypadku użytkowania, ustawodawca nie zdecydował sięna zawarcie kompleksowych regulacji w ustawie z dnia 9 IX 2000 r. o podatku od czynności cywilnoprawnych (Dz. U. 2010 nr 101, poz. 649-j.t., ze zm.), umieszczając w art. 1 ust. $1 \mathrm{w}$ katalogu czynności podlegających opodatkowaniu na gruncie ustawy tylko służebności ustanowione odpłatnie. Z opodatkowaniem wskazanego prawa możemy się spotkać również w ustawie z dnia 28 VII 1983 r. o podatku od spadku i darowizn (Dz. U. 2009 nr 93, poz. 768 - j. t., ze zm.), gdzie zakresem przedmiotowym ustawy objęte tylko i wyłącznie służebności osobiste ustanowione nieodpłatnie. Warto zauważyć również, iż na tle wskazanych ustaw wyłaniają się znaczne odrębności pomiędzy potraktowaniem przez ustawodawcę stużebności osobistych i gruntowych, będących w zasadzie bardzo podobnymi ze względu na konstrukcję i bardzo różniącymi się ze względu na cel ustanowienia.

Celem artykułu jest zbadanie regulacji prawnych związanych z opodatkowaniem służebności osobistych w świetle przepisów wymienionych ustaw. Ze względu na fakt, iż ustanowienie służebności osobistych i gruntowych wywołuje odmienne skutki prawnopodatkowe, przedstawione zostaną podobieństwa i różnice pomiędzy nimi, zezwalające na odpowiednie zaklasyfikowanie ustanowionego przez strony prawa. Następnie dokonana zostanie analiza przepisów prawnych wskazanych powyżej ustaw w celu wyczerpującego przedstawienia problematyki opodatkowania służebności osobistych, ze szczególnym uwzględnieniem wątpliwości interpretacyjnych związanych z obliczaniem podstawy opodatkowania w przypadku nabycia nieodpłatnego, którego dotyczy najnowsze orzecznictwo sądów administracyjnych.

\section{SŁUŻEBNOŚCI OSOBISTE A SŁUŻEBNOŚCI GRUNTOWE}

Służebności należą na mocy art. 244 kodeksu cywilnego (dalej KC) do zamkniętego katalogu ograniczonych praw rzeczowych obok użytkowania, zastawu, spółdzielczego własnościowego prawa do lokalu oraz hipoteki. Ponadto w ich ramach należy wyróżnić służebności:

- osobiste,

- gruntowe,

- przesyłu. 
Wskutek zabiegu legislacyjnego dokonanego przez ustawodawcę, do służebności osobistych odnoszą się zarówno przepisy zawarte $\mathrm{w}$ art. 296-305 KC, jak również odpowiednio przepisy dotyczące służebności gruntowych wskutek odesłania z art. 297 KC oraz przepisy ogólne dotyczące ograniczonych praw rzeczowych, ujęte w Dziale I Tytułu III Księgi II KC. Rozwiązanie przyjęte przez prawodawcę powoduje, że wiele elementów konstrukcyjnych obydwu ograniczonych praw rzeczowych jest podobne, niemniej można wyróżnić zachodzące między nimi znaczne różnice, nie tylko w konstrukcji, ale przede wszystkim w charakterze obydwu oraz pełnionych przez nich funkcjach ${ }^{1}$. Warto zauważyć, iż w przypadku słuzzebności gruntowych nie mamy do czynienia z alimentowaniem każdoczesnego właściciela nieruchomości władnącej, a ze zwiększeniem użyteczności nieruchomości władnącej (art. 285 § 2 KC). Pozwala to na odpowiednie zaklasyfikowanie określonego stanu prawnego odpowiednio jako służebności gruntowych lub osobistych oraz przypisanie określonych skutków na gruncie prawa podatkowego. Należy zaznaczyć wyłaniający się na tle wcześniejszych rozważań wyjątek, budzący dyskusje w doktrynie, mianowicie służebność drogi koniecznej z art. 146 KC, uznanej za przykład służebności osobistej, mimo iż funkcja gospodarcza tego ograniczonego prawa rzeczowego jest bardziej zbliżona do służebności gruntowej².

Na podstawie art. 296 KC należy stwierdzić, iż treść służebności osobistej odpowiada treści służebności gruntowej, czyli można ustanowić służebność osobista, tylko wówczas gdy jest możliwe ustanowienie służebności gruntowej o analogicznej treści. W związku z tym służebność osobista, podobnie jak gruntowa, może polegać na prawie: przechodu, przejazdu, czerpania wody. Innymi przypadkami służebności osobistych są wspomniana wcześniej służebność drogi koniecznej oraz służebność mieszkania, ustanawiana często w testamentach przez spadkodawcę lub w umowach dożywocia. Podobnie jak w przypadku służebności gruntowych, w przypadku służebności osobistych można wyróżnić służebności czynne i bierne, z tym iż najczęściej występują czynne³. Również obydwa rodzaje służebności, ti. gruntowa oraz osobista mogą zostać ustanowione $\mathrm{w}$ drodze:

- umowy,

- $\quad$ orzeczenia sądu (w tym orzeczenia konstytutywnego tylko w sytuacji gdy zezwala na to ustawa, a także wówczas gdy sąd wydaje orzeczenie zastępujące oświadczenie woli strony, która zobowiązawszy się do ustanowienia służebności uchyla się od spełnienia tego zobowiązania) $)^{4}$,

- $\quad$ decyzji administracyjnej (np. w postępowaniu wywłaszczeniowym) ${ }^{5}$.

Ponadto w przypadku służebności gruntowej możliwe jest nabycie jej przez zasiedzenie, gdy polega na korzystaniu Z widocznego i trwałego urządzenia (art. $292 \mathrm{KC})^{6}$. Jeśli chodzi o służebność osobistą to ustawodawca w art. $304 \mathrm{KC}$ wyraźnie wykluczył prawną możliwość ustanowienia jej w drodze zasiedzenia, klasyfikując ją jako res inhabilis. Należy podkreślić w tym miejscu, iż obydwa prawa można ustanowić odpłatnie, jak również nieodpłatnie, za wyjątkiem służebności drogi koniecznej. Jest ona jedynym przykładem służebności osobistych, której ustanowienie zawsze wiąże się Z wynagrodzeniem dla właściciela nieruchomości obciążonej i wskutek tego będzie podlegać opodatkowaniem według przepisów ustawy z dnia 09 IX 2000 r. o podatku od czynności cywilnoprawnych (Dz. U. $2010 \mathrm{nr}$ 101, poz. 649-j.t., ze zm.), o czym będzie mowa w dalszej części artykułu.

Należy wyraźnie zaznaczyć, że w odróżnieniu od służebności gruntowej w przypadku służebności osobistej nie dochodzi do obciążenia nią nieruchomości obciążonej na rzecz każdoczesnego właściciela nieruchomości władnącej. Wynika to z faktu, iż służebność osobistą ustanawia się na rzecz ściśle określonej poprzez wskazanie imienia i nazwiska osoby fizycznej, która nie musi być właścicielem żadnej innej nieruchomości. Można zatem stwierdzić, iż cechą charakterystyczną służebności osobistej jest ścisłe powiązanie z osobą uprawnionego, co powoduje, że jest ona prawem podmiotowo kwalifikowanym, podobnie jak służebność przesyłu? Wynika z tego, iż w świetle obowiązujących przepisów prawnych nie jest możliwe ustanowienie służebności osobistych na rzecz osoby prawnej lub jednostki organizacyjnej nie posiadającej osobowości prawnej. Ściśle wiąże się to z funkcją alimentacyjna, polegającą na zaspokajaniu osobistych potrzeb uprawnio-

1 E. Gniewek (red.), Kodeks cywilny. Księga druga. Własność i inne prawa rzeczowe. Komentarz, Warszawa 2001.

2 A. Kidyba (red.), Kodeks cywilny. Komentarz, T. 2, Warszawa 2010.

3 K. A. Dadańska, Prawo rzeczowe, Warszawa 2012, s. 263.

4 Postanowienie Sądu Najwyższego z dnia 13 II 1974 r. o sygn. akt III CRN 385/73.

5 A. Kidyba (red.), dz. cyt.

6 E. Gniewek (red.), Kodeks cywilny..., dz. cyt.

7 K. Osajda (red.), Kodeks cywilny. Komentarz, Warszawa 2013.

OGRODY NAUK I SZTUK NR 2014 (4) 
nego, którą z założenia powinno spełniać omawiane prawo (art. $296 \mathrm{KC})^{8}$.

W praktyce zachodzą sytuacje, $w$ których pomimo dokonania oznaczenia w umowie określonej osoby fizycznej jako podmiotu uprawnionego z tytułu służebności, będącej równocześnie właścicielem nieruchomości władnącej, nie przesądza jednoznacznie o ustanowieniu służebności osobistych w przypadku braku innych elementów konstrukcyjnych? W takim przypadku zgodnie z zaleceniami Sądu Najwyższego powinna zostać dokonana wykładnia oświadczeń woli stron. Znajduje to odzwierciedlenie w przepisach ustawy z dnia 29 VIII 1997 r. ordynacja podatkowa (Dz. U. z 2013r. poz. 35). Mianowicie w sytuacji, gdy organ podatkowy ma trudności z zaklasyfikowaniem danej umowy powinien zgodnie z art. 199a wziąć pod uwagę zgodny zamiar stron i cel czynności prawnej. Jeśli pomimo przeprowadzonego w tym zakresie postępowania, organ podatkowy dojdzie do przekonania, że pomimo przeprowadzonego postępowania dowodowego nie udało się usunąć tychże wątpliwości, to ma on obowiązek na mocy art. 199a §3 wystąpić do sądu o stwierdzenie istnienia lub nieistnienia stosunku prawnego. W przypadku zatem gdy stwierdzenie czy dana czynność prawna służyła ustanowieniu służebności osobistych czy gruntowych na podstawie treści czynności napotyka znaczne trudności, należy zbadać nie tylko wszystkie elementy konstrukcyjne, które mogą nie zostać wymienione w umowie, ale przede wszystkim funkcje, które ustanowienie danego prawa rzeczowego powinno spełniać.

Różnice pomiędzy obydwoma prawami można zauważyć analizując sposób ich wykonywania. Zakres służebności w obu przypadkach strony powinny ustalić w umowie, lecz ogólne dyrektywy odnośnie zakresu i sposobu wykonywania wyznaczają odpowiednio art. 287 i 288 KC w przypadku służebności gruntowych oraz art. 298 KC w przypadku służebności osobistych (wraz z regulacją szczególną wynikającą z art. $302 \mathrm{KC}$ dotyczącej służebności mieszkania). Zakres i sposób wykonywania służebności osobistych powinien być oznaczony w przypadku braku innych ogólnie dostępnych danych według zasad współżycia społecznego przy uwzględnieniu zwyczajów miejscowych, zaś wykonywanie tego prawa powinno następować w taki sposób, by jak najmniej utrudniało korzystanie z nieruchomości obciążonej. W przypadku służebności osobistych w oznaczeniu zakresu i sposobu wykonywania uwzględnia się ponadto osobiste potrzeby uprawnionego, co związane jest z pełnionymi przez nie funkcjami. Jeśli zaś chodzi o służebność mieszkania to w jej przypadku mamy do czynienia z regulacją szczególną wobec art. 298 KC. Na mocy art. $302 \S 1$ KC uprawniony może ponadto korzystać z pomieszczeń i urządzeń przeznaczonych do wspólnego użytku mieszkańców budynku10

Nic nie stoi na przeszkodzie by służebność gruntową ustanowić na czas określony lub nieokreślony, w zależności od woli stron. Jeśli chodzi o służebność osobista, to można ją ustanowić tylko i wyłącznie na czas oznaczony, co ściśle związane jest z jej charakterem oraz funkcja. Możliwość ustanowienia jej na czas nieokreślony przeczyłaby celowi służebności osobistej wyrażonemu w art. $298 \mathrm{KC}$, gdyż w pewnym momencie przestałaby służyć osobie uprawnionej.Z tego względu prawo to na mocy art. $299 \mathrm{KC}$ powinna wygasnąc najpóźniej z chwilą śmierci osoby uprawnionej ${ }^{11}$.

Ze ściśle osobistym charakterem służebności gruntowej związany jest zakaz jej zbywania oraz przenoszenia uprawnienia do jej wykonywania na inną osobę (art. 300). Poza przypadkiem służebności osobistej mieszkania, gdy strony mogą postanowić w umowie, że po śmierci osoby uprawnionej będzie ona przysługiwać określonym osobom najbliższym dla zmarłego (małżonkowi, rodzicom, dzieciom). Regułą jest jednakże norma imperatywna wyrażona w art. $300 \mathrm{KC}$, zaś regulacja zawarta w art. $301 \S 2 \mathrm{KC}$ ze względu na swój dyspozytywny charakter będzie mogła znaleźć zastosowanie, gdy taki będzie zgodny zamiar stron. W przeciwieństwie od niniejszych uregulowań, stużebności gruntowe są prawem związanym z własnością nieruchomości, stanowiąc jej część składową i na mocy art. 50 w zw. z art. 47 §1 KC dzielą los prawny nieruchomości. Skoro własność nieruchomości jest prawem zbywalnym i przenoszalnym, nic nie stoi na przeszkodzie zbyciu nieruchomości gruntowej wraz z nieruchomością. Niemożliwe jest jednakże przeniesienie służebności gruntowej na inny podmiot prawa bez przeniesienia własności nieruchomości.

Zarówno służebność gruntowa, jak i osobista na wskutek odpowiedniego stosowania przepisów ogólnych o ograniczonych prawach rzeczowych oraz w przypadku służebności odpowiedniego stosowania również przepisów o służebnościach gruntowych, mogą wygasnąc m.in. w drodze konfuzji, zrzeczenia się, umowy stron, orzeczenia sądu, niewykonywanie przez lat dziesięć. Odmienność regulacji prawnych w kwestii wygaśnięcia obydwu praw można zauważyć w przypadku wygaśnięcia ich za wynagrodzeniem. Odnośnie służebności gruntowych możliwe jest na mocy art. $294 \mathrm{KC}$

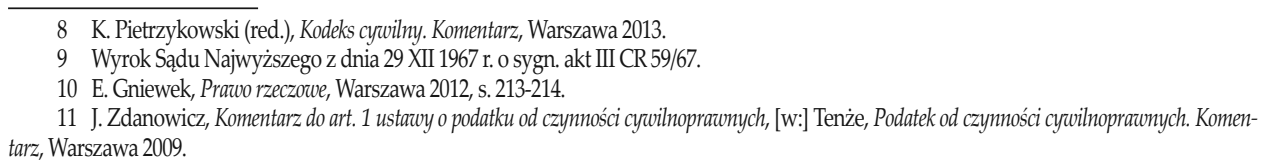


zniesienie ich za wynagrodzeniem, gdy wskutek zmiany stosunków stała się ona zbyt uciążiwa dla właściciela nieruchomości obciążonej, zaś nie jest konieczna do korzystania z nieruchomości władnącej. Jeśli zaś służebność gruntowa utraciła dla nieruchomości władnącej wszelkie znaczenie, możliwe jest żądanie jej zniesienia bez wynagrodzenia (art. $295 \mathrm{KC}$ ). Podmiotem uprawnionym do wysunięcia żądań na mocy art. 294 i 295 KC jest tylko i wyłącznie właściciel nieruchomości obciążonej. W przypadku służebności gruntowych na mocy art. 303 KC właścicielowi nieruchomości obciążonej zostało przyznane uprawnienie żądania zamiany tego prawa na rentę pieniężna, w sytuacji gdy uprawniony z tytułu służebności dopuszcza się rażących uchybień w wykonywaniu swojego prawa. Podobnie jak w przypadku opisanej poprzednio regulacji, podmiotem uprawnionym do wystąpienia z takim żądaniem jest właściciel nieruchomości obciążonej. Stużebność osobista może być również zamieniona na rentę lub może wobec niej dojść do zmiany treści służebności, w przypadku gdy nieruchomośćnią obciążona zostanie wniesiona jako wkład do rolniczej spółdzielni produkcyjnej (art. 304 KC). W odróżnieniu od służebności gruntowej, niemożliwe jest we wskazanych przypadkach zniesienie służebności osobistej bez wynagrodzenia, co wiąże się z ochroną osoby uprawnionej z jej tytułu.

\section{SŁUŻEBNOŚCI OSOBISTE W PODATKU OD CZYNNOŚCI CYWILNOPRAWNYCH}

Opodatkowaniu służebności ustawodawca dał wyraz na gruncie podatków majątkowych między innymi w ustawie z dnia 09 IX 2000 r. o podatku od czynności cywilnoprawnych (Dz. U. $2010 \mathrm{nr}$ 101, poz. 649-j.t., ze zm.). W art. 1 ust. 1 ustawy został wskazany zakres przedmiotowy opodatkowania podatkiem od czynności cywilnoprawnych. Ze względu na zawarcie przez ustawodawcę we wskazanym przepisie katalogu zamkniętego czynności podlegających opodatkowaniu niemożliwa jest wykładnia rozszerzająca ${ }^{12}$. Na mocy art. 1 ust.1 podlegają mu tylko określone czynności prawne dokonywane w ramach umów nazwanych lub mające na celu ustanowienie ściśle określonych ograniczonych praw rzeczowych, do których należy między innymi odpłatnie ustanowiona służebność na podstawie umowy stron lub orzeczenia sądu ${ }^{13}$ (art. 1 ust. 1 lit. i). Należy zwrócić uwagę, iż w ramach analizowanego przepisu ustawodawca nie rozróżnił służebności osobistych od innych rodzajów tego ograniczonego prawa rzeczowego, wskutek czego należy uznać, iż opodatkowaniu podlega każda ustanowiona służebność, jeśli cechuje się odpłatnościa, która w przypadku służebności jest fakultatywna. Ze względu na fakt, iż stanowiąca przypadek służebności osobistej, służebność drogi koniecznej jest ustalana zawsze za wynagrodzeniem, będzie zawsze podlegać opodatkowaniu podatkiem od czynności cywilnoprawnych. Poza zakresem przedmiotowym ustawy znajdują się ustanowione nieodpłatnie służebności gruntowe i przesyłu, w przypadku zaś służebności osobistych ustanowionych nieodpłatnie ustawodawca postanowił objąć ich opodatkowanie podatkiem od spadków i darowizn, o czym będzie mowa w dalszej części artykułu.

Podatnikiem podatku od czynności cywilnoprawnych, czyli podmiotem na którym ciąży obowiązek zapłaty podatku, jest zgodnie z art. 4 pkt. 6 ustawy nabywca służebności ${ }^{14}$. W przypadku służebności gruntowej będzie to więc właściciel nieruchomości władnącej, w przypadku służebności osobistej oznaczona osoba fizyczna uprawniona z tytułu ustanowionego prawa, zaś w przypadku służebności przesyłu przedsiębiorca zamierzający wybudować urządzenie, o którym mowa w art. $49 \S 1 \mathrm{KC}$ lub będący właścicielem takiego urządzenia. Istotną kwestią jest moment powstania obowiązku podatkowego, którym na mocy art. 3 ust. 1 ustawy jest chwila ustanowienia odpłatnej stużebności. Warto zaznaczyć, iż w przypadku gdy przedsiębiorcą w przypadku służebności przesyłu są wspólnicy spółki cywilnej, obowiązek zapłaty podatku ciąży na nich solidarnie (art. 5). Zgodnie z art. 10 podatnik powinien bez dodatkowego wezwania organu podatkowego złożyć deklarację, obliczyć i wpłacić należny podatek w terminie 14 dni od ustanowienia prawa.

Podatek z tytułu ustanowienia odpłatnej służebności obliczany jest od podstawy opodatkowania, którą w tym przypadku jest wartość świadczeń osoby, na rzecz której ją ustanowiono. Należy dodać, iż powyższą wartość przyjmuje się za okres, na jaki prawa te zostały ustanowione. Zgodnie z art. 6 ust. 6 za podstawę opodatkowania należy przyjąć zgodnie z oświadczeniem podatnika:

- wartość świadczeń za 10 lat,

- $\quad$ wartość świadczeń należnych w miarę wykonywania umowy.

Ponadto w sytuacji gdy dojdzie do zmiany umowy ustanowienia odpłatnej służebności, za podstawę opodatkowania należy przyjąć:

- $\quad$ wartość świadczeń za okres na jaki została ustanowiona służebność, wartość świadczeń za 10 lat lub w miarę

12 Ł. Matusiakiewicz, Czynności prawne niepodlegajace PCC w oparciu o zasadę numerus clausus, Warszawa 2013.

13 T. Nierobisz, A. Waclawczyk, Podatek od czynności cywilhoprawnych. Komentarz, Warszawa 2011.

14 Tamże. 
wykonywania umowy, lub wartość wszystkich świadczeń za czas trwania tego prawa (tylko za zgodą podatnika) - w sytuacji gdy wskutek zmiany umowy doszło do przedłużenia okresu jej trwania,

- różnica wartości obliczonej według wskazań w poprzednim myślniku - w sytuacji gdy poprzez zmianę umowy dochodzi do zmiany wysokości świadczeń.

Na mocy art. 6 ust. 3 można stwierdzić, iż w przypadku gdy podatnik nie określił wartości ograniczonego prawa rzeczowego, którym w tym przypadku będzie odpłatnie ustanowiona służebność, na poziomie wartości rynkowej, wówczas na organie podatkowym ciąży obowiązek wezwania podatnika do określenia tej wartości (a także jej podwyższenia lub obniżenia). W tym celu organ podatkowy ma obowiązek wyznaczyć podatnikowi odpowiedni termin, niemniej nie krótszy niż 14 dni liczonych od dnia doręczenia wezwania. Poza tym we wspomnianym wezwaniu organ podatkowy powinien $\mathrm{w}$ wezwaniu podać wartość przyjętą za rynkową według własnej wstępnej oceny. W przypadku gdy po otrzymaniu wezwania podatnik nie podał wartości świadczeń lub nie odpowiadała ona wartości rynkowej, na organie podatkowym ciąży obowiązek jej określenia z uwzględnieniem opinii biegłego lub przedłożonej przez podatnika wyceny rzeczoznawcy. Należy niemniej pamiętać, iż w przypadku gdy wartość przedmiotu depozytu nieprawidłowego określona na podstawie opinii biegłego różni się o więcej niż 33\% od podanej przez podatnika, koszty opinii ponosi podatnik (art. 6 ust. 4).

Na mocy art. 7 ust. 1 pkt. 3 do ustalonej w powyższy sposób podstawy opodatkowania należy zastosować stawkę podatkową w wysokości 1\%. Należy wyraźnie zaznaczyć, iż w przypadku ustanowienia służebności organ podatkowy nie ma prawa zastosować stawki sankcyjnej określonej w art. 7 ust. 5 w okoliczność w nim wymienionych. Opodatkowanie według stawki sankcyjnej można zastosować wobec ograniczonych praw rzeczowych tylko i wyłącznie w przypadku użytkowania ustanowionego odpłatnie (w tym również użytkowania nieprawidłowego), o czym informuje art. 7 ust. 1 pkt. $3 \mathrm{w}$ zw. $\mathrm{z}$ art. 7 ust. 5 pkt. 1. Jeśli podatnik nie wpłaci w terminie należnego podatku z tytułu ustanowienia odpłatnej służebności naraża się w tym przypadku na zapłatę odsetek za opóźnienie, niemniej należny podatek zostanie również i w tym przypadku obliczony z zastosowaniem stawki $1 \%$.

Warto zwrócić uwagę na fakt, iż uprawniony z tytułu służebności nie będzie zobowiązany do zapłaty podatku mimo powstania obowiązku podatkowego, jeśli stronami umowy, w której nastąiło ustanowienie tego prawa są podmioty wymienione $\mathrm{w}$ katalogu zwolnień podmiotowych $\mathrm{z}$ art. 8. Równocześnie warto zauważyć, że ustanowienie odpłatnych służebności nie znajduje się w zamkniętym katalogu zwolnień przedmiotowych z art. 9, wskutek czego niemożliwe będzie zwolnienie podatnika od zapłaty podatku $\mathrm{z}$ tego tytułu.

\section{SŁUŻEBNOŚCI OSOBISTE W PODATKU OD SPADKÓW I DAROWIZN}

Jak wykazano w poprzednim rozdziale, podatkowi od czynności cywilnoprawnych podlega odpłatne ustanowienie służebności. W przypadku służebności ustanawianych bez wynagrodzenia, ustawodawca zdecydował się na opodatkowanie ich według przepisów ustawy z dnia 28 VII 1983 r. o podatku od spadku i darowizn (Dz. U. 2009 nr 93, poz. 768 -j. t., ze zm.), co może być związane z faktem, iż podatek od spadków i darowizn wymierzany jest od przyrostu substancji majątku, którzy przysparzany jest w sposób nieodpłatny ${ }^{15}$.Ze względu na to, iż opodatkowaniu podatkiem od spadków i darowizn podlega nabycie rzeczy lub praw majątkowych (w tym również ograniczonych praw rzeczowych ${ }^{16}$ ) przez osoby fizyczne, niemożliwe jest stosowanie przepisów ustawy do ustanowienia nieodpłatnych służebności gruntowych oraz przesyłu ze względu na kwalifikację podmiotową ${ }^{17}$. Ponadto opodatkowaniu na gruncie przywołanej ustawy będzie podlegało ustanowienie służebności osobistej, która ma być wykonywana na terytorium Rzeczpospolitej Polskiej (art. 1 ust.1). Dokonując uważnej analizy art. 1 można dojść do wniosku, iż skoro służebności gruntowe oraz przesyłu ${ }^{18}$ można zasiedzieć, to takie zasiedzenie będzie opodatkowane podatkiem od spadków i darowizn. Należy jednakże zauważyć, iż w tym przypadku ustawodawca nakłada na podatnika obowiązek zapłaty podatku ze względu na fakt zasiedzenia, nie zaś ustanowienia w ten sposób służebności. Z tego względu w powyższej sytuacji znajdzie zastosowanie stała stawka podatku, zaś podatek nie będzie obliczany według grup podatkowych ${ }^{19}$. Na marginesie można zauważyć, że nie dojdzie do opodatkowania nieodpłatnej służebności osobistej podatkiem od spadków i darowizn, w przypadku gdy stanowi ona integralną część umowy dożywocia. Wówczas dochodzi do opodatkowania dożywocia podatkiem od czynności cywilnoprawnych.

15 Wyrok Sądu Administracyjnego w Gliwicach z 6 XII 2010 r. o sygn. akt ISA/Gl 752/10.

16 S. Brzeszczyńska, Podatek od spadków i darowizn. Komentarz, Warszawa 2009.

17 Pismo Ministerstwa Finansów z dnia 16 I 2007 r. o sygn. PL-834/85/JB/06/PDJC-345/06/39/07.

18 S. Babiarz, A. Mariański, W. Nykiel, Ustawa o podatku od spadków i darowizn. Komentarz, Warszawa 2010.

19 K. Święch, Pozycja rodziny w polskim prawie podatkowym, Warszawa 2013. 
Wspomniano powyżej, że na gruncie ustawy opodatkowaniu podlegają prawa majątkowe, które wykonywane są na terytorium Rzeczpospolitej Polskiej. Należy niemniej wyraźnie zaznaczyć, że wyłączeniu spod opodatkowania podatkiem od spadków i darowizn w przypadku ustanowienia nieodpłatnych służebności wyłączone zostało nabycie ich w przypadku gdy podlegają wykonaniu na terytorium Rzeczypospolitej Polskiej, jeżeli w dniu ich nabycia osoba uprawniona z tytułu służebności nie była obywatelem polskim i nie miał miejsca stałego pobytu na terytorium Rzeczypospolitej Polskiej (art. 3 pkt.1.). Można więc zauważyć, że wobec podlegania podatkowi od spadków i darowizn ustawodawca przyjął mieszaną koncepcję obywatelstwa i domicylu. W przypadku nieodpłatnego ustanowienia służebności nie jest możliwe skorzystanie ze zwolnień przedmiotowych, gdyż nie znajdują się one w zamkniętym katalogu z art. 4. Możliwe jest jednakże skorzystanie ze zwolnienia podmiotowego z art. 4a, o czym szerzej w dalszej części artykułu.

Na mocy art. 5 podatnikiem podatku od spadków i darowizn z tytułu ustanowienia nieodpłatnej służebności jest nabywca tego ograniczonego prawa rzeczowego, czyli konkretnie osoba uprawniona z tytułu wskazanej służebności osobistej. Obowiązek podatkowy powstanie z chwiląjej ustanowienia, o czym informuje art. 6 ust. 1 pkt. 8. Szczególnie ciekawa kwestia w przypadku opodatkowania nieodpłatnie ustanowionej służebności osobistej powstaje przy obliczeniu podstawy jej opodatkowania. Według art. 7 podstawę opodatkowania stanowi wartość nabytych rzeczy i praw majątkowych po potrąceniu długów i ciężarów, czyli tzw. czysta wartość. Ustala się ją według stanu wspomnianego ograniczonego prawa majątkowego $\mathrm{w}$ dniu nabycia, przyjmując ceny rynkowe z dnia powstania obowiązku podatkowego. Jeżeli przed dokonaniem wymiaru podatku nastąi ubytek rzeczy spowodowany siłą wyższa, do ustalenia wartości przyjmuje się stan rzeczy w dniu dokonania wymiaru, a odszkodowanie za ubytek należne z tytułu ubezpieczenia wlicza się do podstawy wymiaru. Jeżeli nabywca nie określił wartości nabytej służebności albo wartość określona przez niego nie odpowiada, według oceny naczelnika urzędu skarbowego wartości rynkowej, to podobnie jak w przypadku podatku od czynności cywilnoprawnych, organ podatkowy powinien wezwać nabywcę do jej określenia, podwyższenia lub obniżenia, $\mathrm{w}$ terminie nie krótszym niż 14 dni od dnia doręczenia wezwania. Równocześnie organ podatkowy powinien podać we wskazanym wezwaniu wartość według własnej, wstępnej oceny. Według art. 8 ust. $5 \mathrm{w}$ przypadku gdy nabywca mimo wezwania nie określił wartości, albo podał wartość, która nie odpowiada wartości rynkowej, naczelnik urzędu skarbowego dokona jej określenia z uwzględnieniem opinii biegłego lub przedłożonej przez nabywcę wyceny rzeczoznawcy. W pierwszym z przywołanych przypadków gdy wartość określona z uwzględnieniem opinii biegłego różni się o więcej niż 33\% od wartości podanej przez nabywcę, koszty opinii biegłego ponosi nabywca.

Przyjmuje się, że dniem nabycia w przypadku służebności jest dzień zawarcia umowy lub dokonania jednostronnego oświadczenia woli, zaś dniem obowiązku podatkowego dzień jej ustanowienia ${ }^{20}$. Z uregulowaniami przyjętymi w art. 6 ustawy z dnia 09 IX 2000 r. o podatku od czynności cywilnoprawnych (Dz. U. 2010 nr 101, poz. 649-j.t., ze zm.) koresponduje art. 13 ustawy z dnia 28 VII 1983 r. o podatku od spadku i darowizn (Dz. U. 2009 nr 93, poz. 768 -j. t., ze zm.). Zgodnie z ust. 1 wspomnianego art. 13 jako podstawę opodatkowania przyjmuje się wartość świadczeń powtarzających się w wysokości rocznego świadczenia, które następnie ulega pomnożeniu:

- $\quad$ przez liczbę lat lub odpowiednio ich części - w przypadku ustanowienia nieodpłatnej służebności osobistej na czas określony (co do liczby lat lub ich części),

- $\quad$ przez okres 10 lat - w pozostałych przypadkach, gdy ustanowiono wskazane wyżej ograniczone prawo rzeczowe na czas nieokreślony.

Przez wskazany powyżej okres czasu zgodnie z art. 13 ust. 3 przemnaża się przez 4\% rocznej wartości nieruchomości obciążonej służebnościa, tak więc jeśli służebność taka została ustanowiona na czas nieokreślony, podstawa opodatkowania wynosi 40\% wartości nieruchomości. Przy określeniu w ten sposób podstawy opodatkowania pojawiają się liczne kontrowersje. Ze względu na fakt, iż niemożliwe jest ustanowienie służebności na części nieruchomości, za podstawę należy przyjąc wartość całej nieruchomości ${ }^{21}$.Dotyczy to sytuacji gdy wprawdzie ustanowiono nieodpłatną służebność mieszkania, lecz obdarowany korzysta z jednego pokoju. Wówczas wartość tego prawa powinna być liczona nie od powierzchni tegoż pokoju, tylko od powierzchni całej nieruchomości, co prowadzi do zwielokrotnienia podstawy opodatkowania. W praktyce uznawano również, że na podstawę opodatkowania służebności osobistej nie ma wpływu fakt ustanowienia jej na rzecz kilku osób na tej samej nieruchomości, gdyż każda z nich ma prawo korzystania z całej nieruchomości obciążonej ${ }^{22}$. Odmienne stanowisko od powyższego można spotkać w orzeczeniach sądów administracyjnych, które opierają

20 S. Brzeszczyńska, dz. cyt.

21 Wyrok Sądu Najwyższego z dnia 4 VII 1960 r. o sygn. akt I CR 347/60.

22 Tamże. 
się o wykładnię systemowa ustawy oraz wykładnię prokonstytucyjna, ze względu na fakt, iż obliczona w powyższy sposób podstawa nie uwzględniałaby wartości rzeczywiście nabytego prawa. Powyższe stanowisko zaprezentował między innymi Wojewódzki Sąd Administracyjny w Białymstoku w wyroku z dnia 10 VII 2013 r. według którego podstawę opodatkowania stanowi czysta wartość służebności, z której podatnik ma faktyczną możliwość korzystania, w związku z czym jeżeli podatnik nabył prawo do korzystania z części budynku mieszkalnego to jedynie wartość tej części powinna stanowić podstawę do wyliczenia wartości nabytego prawa ${ }^{23}$. Wedle stanowiska prezentowanego przez judykaturę, niemożliwe jest oparcie wykładni art. 13 tylko o cywilistyczne pojęcie służebności osobistych, nie biorąc pod uwagę zasady proporcjonalności oraz racjonalności opodatkowania. Nie uwzględnienie tych zasad prowadziłoby do niczym nieuzasadnionego fiskalizmu organów podatkowych, który trudno byłoby pogodzić z racjonalnością ustawodawcy oraz zasadą sprawiedliwości społecznej. Reasumując, w ocenie sądów administracyjnych tylko wartość faktycznie nabytego prawa może stanowić podstawę opodatkowania podatkiem od spadków i darowizn, co ma na celu zagwarantowanie niedopuszczenia do opodatkowania prawa w zakresie, $w$ jakim strona go w istocie nie nabyła ${ }^{24}$. Podobne konkluzje można znaleźć również w innych wyrokach ${ }^{25}$.

Wysokość podatku obliczana jest $\mathrm{z}$ zastosowaniem podanych przez ustawodawcę $\mathrm{w}$ art. 14 grup podatkowych, do których zalicza się nabywcę, którym w przypadku ustanowienia nieodpłatnej służebności osobistej jest uprawniony z jej tytułu. Trafne zaklasyfikowanie nabywcy do określonej grupy jest o tyle istotne, iż w oparciu o grupę podatkową dokonuje się przypisania odpowiedniej kwoty wolne, skali podatkowej oraz obliczenia w ten sposób należnego podatku. Według art. 14:

- do grupy I podatkowej zalicza się : małżonka, zstępnych, wstępnych, pasierba, zięcia, synowa, rodzeństwo, ojczyma, macochę i teściów, przy czym za rodziców przyjmuje się również przysposabiających, zaś za dzieci przysposobionych;

- $\quad$ do II grupy podatkowej zalicza się: zstępnych rodzeństwa, rodzeństwo rodziców, zstępnych i małżonków pasierbów, małżonków rodzeństwa i rodzeństwo małżonków, małżonków rodzeństwa małżonków, małżonków innych zstępnych;

- $\quad$ do III grupy podatkowej zalicza się innych nabywców niż wymienionych powyżej.

W tym miejscu należy nawiązać do zwolnienia podmiotowego z art. 4a, który jest regulacją szczególną wobec art. 14. Zgodnie z brzmieniem wspomnianego przepisu zwolnieniu podmiotowemu podlega nabycie nieodpłatnej stużebności osobistej przez małżonka, zstępnych, wstępnych, pasierba, rodzeństwo, ojczyma i macochę, czyli podmiotów należących do I grupy podatkowej, pod warunkiem zgłoszenia nabytego prawa majątkowego naczelnikowi urzędu skarbowego $\mathrm{w}$ terminie 6 miesięcy od dnia powstania obowiązku podatkowego powstałego na podstawie art. 6 ust. 1 pkt 2-8 i ust. 2. Jeśli wskazany warunek nie zostanie spełniony, nabycie nieodpłatnej służebności osobistej podlega opodatkowaniu na zasadach określonych dla nabywców zaliczonych do I grupy podatkowej.

Zgodnie z powyższym i na podstawie art. 15 dokonuje się obliczenia podatku, stosując odpowiednią dla danej grupy podatkowej skalę. W przypadku gdy nabywca należy do I grupy podatkowej, do kwoty 10278 zł podatek wynosi 3\% podstawy opodatkowania, zaś gdy wartość podstawy opodatkowania mieści się między 10278 zł a 20556 zł należny podatek wynosi 308, $30 \mathrm{zł}$ oraz 5\% nadwyżki ponad 10278 zł. Jeśli podstawa opodatkowania przekracza 20556 zł to należny podatek powinien wynieść 822,20 zł i 7\% nadwyżki ponad 20556 zł. Przy ustalaniu należnego podatku należy pamiętać, iż przyjmuje się wartość służebności na dzień powstania obowiązku podatkowego. Ponadto w zależności od grupy podatkowej, nabycie nieodpłatnie ustanowionej służebności podlega zwolnieniu, jeśli jej czysta wartość nie przekracza określonej przez ustawodawcę kwoty wolnej z art. 9 ustawy. Przykładowo, dla pierwszej grupy podatkowej kwota wolna wynosi 9637 zł i jeśli czysta wartość wspomnianej służebności jej nie przekroczy to nabycie służebności nie podlega opodatkowaniu na gruncie podatku od spadków i darowizn.

23 Wyrok Wojewódzkiego Sądu Administracyjnego w Białymstoku z dnia 10 VII 2013 r. o sygn. akt I SA/Bk 119/13.

24 Wyrok Wojewódzkiego Sądu Administracyjnego w Krakowie z dnia 11 VI 2013 r. o sygn. akt I SA/Kr 843/12.

25 Zob. Wyrok NSA z dnia 28 II 2007 r. o sygn. akt II FSK 335/06; Wyrok Wojewódzkiego Sądu Administracyjnego w Warszawie z dnia 29 IX 2011r. o sygn. akt. III SA/Wa 310/11. 


\section{ZAKOŃCZENIE}

Na podstawie wniosków wypływających z niniejszego artykułu można stwierdzić, iż ustawodawca zdecydował się na prawne wyodrębnienie opodatkowania ustanowienia nieodpłatnych służebności osobistych ze względu na cel przyświecający podatkowi od spadków i darowizn, którym jest opodatkowanie nieodpłatnych przysporzeń majątkowych dokonanych na rzecz nabywcy rzeczy lub praw znajdującego się w określonej grupie podatkowej. Nie oznacza to jednakże, że w przypadku nieodpłatnych służebności osobistych nie można spotkać się z opodatkowaniem podatkiem od czynności cywilnoprawnych - taka sytuacja w przypadku gdy stanowią one integralną część umowy dożywocia, niemniej opodatkowaniu podlega tylko umowa dożywocia, mimo występowania w jej ramach służebności. Podobna sytuacja zachodzi w przypadku zasiedzenia służebności gruntowych oraz służebności przesyłu, które opodatkowane jest podatkiem od spadku i darowizn ze względu na dokonane zasiedzenie - nie ma znaczenia w tym przypadku charakter zasiedzianego prawa oraz przynależność nabywcy prawa do określonej grupy podatkowej.

Generalnie ustawodawca rozdzielił skutki prawne wywoływane przez ustanawiane odpłatnie służebności oraz nieodpłatne służebności majątkowe. Rozróżnienie pomiędzy służebnościami osobistymi a gruntowymi traci na znaczeniu w przypadku podatku od czynności cywilnoprawnych, niemniej jest bardzo istotne dokonanie odpowiedniej klasyfikacji wobec nieodpłatnych służebności gruntowych i osobistych, gdyż podlegają one opodatkowaniu według innego podatku. Z tego względu celowe było wskazanie różnic i podobieństw pomiędzy służebnościami osobistymi a służebnościami gruntowymi ukazane w pierwszym rozdziale. Następnie dokonano szczegółowej analizy przepisów prawnych odnoszących się do opodatkowania służebności osobistych w ramach podatku od czynności cywilnoprawnych oraz podatku od spadków i darowizn, by kompleksowo przedstawić problematykę ich opodatkowania na gruncie podatków majątkowych przez pryzmat elementów konstrukcyjnych podatku. Skupiono się w szczególności na budzącej kontrowersje kwestii obliczenia podstawy opodatkowania w podatku od spadku i darowizn w przypadku gdy osoba uprawniona z tytułu służebności korzysta z części nieruchomości obciążonej.

\section{Bibliografia}

Teksty źródłowe, akty prawne

[1] Pismo Ministerstwa Finansów z dnia 16 I 2007r. o syon. PL-834/85/B/06/PDJC-345/06/39/07.

[2] Postanowienie Sądu Najwyższego z dnia 13 II 1974 r. o sygn. akt III CRN 385/73.

[3] Ustawa z dnia 23 IV 1964 r. kodeks cywilny (Dz. U nr 16, poz. 93 z późn. zm.).

[4] Ustawa z dnia 09 IX 2000 r. o podatku od czynności cywilnoprawnych (Dz. U. $2010 \mathrm{nr}$ 101, poz. 649 - j. t., z późn. zm.)

[5] Ustawa z dnia 28 lipca 1983 r. o podatku od spadku i darowizn (Dz.U. 2009 nr 93, poz. 768 -j.t., ze zm.).

[6] Wyrok Sądu Najwyższego z dnia 29 XII 1967 r. o sygn. akt III CR 59/67.

[7] Wyrok Sądu Najwyższego z dnia 4 VII 1960 r. o sygn. akt ICR 347/60.

[8] Wyrok Sądu Administracyjnego w Gliwicach z 6 XII 2010 r. o sygn. akt ISA/Gl 752/10.

[9] Wyrok Wojewódzkiego Sądu Administracyjnego w Białymstoku z dnia 10 VII 2013 r. o sygn. akt I SA/Bk 119/13.

[10] Wyrok Wojewódzkiego Sądu Administracyjnego w Krakowie z dnia 11 VI 2013 r. o sygn. akt I SA/Kr 843/12.

\section{Książki/czasopisma}

[11] Babiarz S., Mariański A., Nykiel W., Ustawa o podatku od spadków i darowizn. Komentarz, Warszawa 2010.

[12] Brzeszczyńska S., Podatek od spadków i darowizn. Komentarz, Warszawa 2009.

[13] Dadańska K. A., Prawo rzeczowe, Warszawa 2012.

[14] Gniewek E. (red.), Kodeks cywilny. Księga druga. Własność i inne prawa rzeczowe. Komentarz, Warszawa 2001.

[15] Gniewek E., Prawo rzeczowe, Warszawa 2012

[16] Kidyba A. (red.), Kodeks cywilny. Komentarz, T. 2, Warszawa 2010.

[17] Matusiakiewicz Ł., Czynności prawne niepodlegające PCC w oparciu o zasadę numerus clausus, Warszawa 2013.

[18] Nierobisz T., Wacławczyk A., Podatek od czynności cywilnoprawnych. Komentarz, Warszawa 2011.

[19] Osajda K. (red.), Kodeks cyzvilny. Komentarz, Warszawa 2013

[20] Pietrzykowski K. (red.), Kodeks cywilny. Komentarz, Warszawa 2013.

[21] Święch K., Pozycja rodziny w polskim prawie podatkowym, Warszawa 2013.

[22] Zdanowicz J., Komentarz do art. 1 ustawy o podatku od czynności cywilnoprawnych, [w:] Zdanowicz J., Podatek od czynności cywilnoprawnych. Komentarz, Warszawa 2009 